\title{
Desain Pembelajaran Pendidikan Islam Berbasis Neurosains: Peran Musik, Pencahayaan dan Tata Ruang
}

\author{
Tian Khusni Akbar ${ }^{1 *}$ dan Suyadi ${ }^{2}$ \\ Universitas Ahmad Dahlan ${ }^{1 *}$ \\ ${ }^{*}$ eemail: tian2007052024@webmail.uad.ac.id \\ 2 email: 2 suyadi@fai.uad.ac.id
}

\begin{abstract}
This study aims to analyze the design of Islamic educational learning through the art of music, lighting and spatial neuroscience perspectives. This is important because Islamic education has not yet maximized innovative learning methods in using the learning model. This research approach is qualitative type of literature. The data sources of this study are literature in the fields of music, spatial lighting, Islamic education and neuroscience. The collected data is then analyzed qualitatively using inductive thinking patterns. The results showed that the design of learning through music is able to optimize human brain function in both emotions, motivation, to positive actions, because the right and left brains functioning means that the cognitive and psychomotor aspects function optimally. Optimization of lighting in the study room has a great effect on the brain because most of the human brain receives information / knowledge through the human eye. Spatial design in learning is the optimization of the learning room in order to provide a sense of security and comfort in the learning process.
\end{abstract}

Keywords: Islamic Education, Neuroscience, Music, Lighting and Spatial Planning.

\begin{tabular}{l}
\hline Abstrak \\
\hline Penelitian ini bertujuan untuk menganalisis desain \\
pembelajaran pendidikan Islam melalui seni musik, \\
pencahayaan dan tata ruang perspektif neurosains. Hal ini \\
penting dilakukan karena pendidikan Islam saat ini belum \\
memaksimalkan metode pembelajaran secara inovatif dalam \\
menggunakan model pembelajaran. Pendekatan penelitian ini \\
adalah kualitatif jenis kepustakaan. Sumber data penelitian \\
ini merupakan literatur di bidang musik, pencahayaan tata \\
ruang, pendidikan Islam dan neurosains. Teknik \\
\hline \hline
\end{tabular}

Artikel Info

Received:

22 January 2021

Revised:

20 May 2021

Accepted:

28 May 2021

Published:

10 June 2021 
pengumpulan data dilakukan dengan menelusuri referensi terkait, baik secara manual maupun digital, terutama dalam data base google cendekia dengan kata kunci yang digunakan adalah desain pembelajaran pendidikan Islam, neurosains, musik, pencahayaan dan tata ruang. Data yang terkumpul kemudian dianalisis secara kualitatif dengan menggunakan pola berpikir induktif. Hasil penelitian menunjukkan bahwa desain pembelajaran melalui musik mampu mengoptimalkan fungsi otak manusia baik pada emosi, motivasi, hingga tindakan positif, karena otak kanan dan kiri berfungsi artinya aspek kognitif dan psikomotoriknya berfungsi secara optimal. Pengoptimalan pencahayaan pada ruang belajar memilki efek yang besar terhadap otak karena sebagian besar otak manusia menerima informasi/pengetahuan melalui mata manusia. Desain tata ruang dalam pembelajaran adalah optimalisasi ruang belajar agar memberikan rasa aman dan nyaman dalam proses pembelajaran.

Kata Kunci : Pendidikan Islam, Neurosains, Musik, Pencahayaan dan Tata ruang.

\section{A. Pendahuluan}

Majunya dunia pendidikan di Indonesia tidak terlepas dari model pembelajaran yang semakin kreatif dan inovatif. Keberhasilan pembelajaran tidak hanya diukur dari nilai kognitif siswa. Akan tetapi, dari seluruh aspek pendukung dalam pembelajaran, baik guru, orang tua, siswa maupun lingkungan belajar. Model dan metode pembelajaran yang kuno merupakan sesuatu yang harus ditinggalkan, karena dianggap tidak lagi relevan dengan kemajuan zaman. Seperti halnya ruang belajar yang stagnan sehingga menjadikan tingkat rangsangan otak menurun, maka hal ini berpengaruh terhadap kecerdasan otak siswa. Berbagai gejala ketidakstabilan siswa pada saat belajar terlihat dari proses belajar siswa dan hasil belajar siswa. Fenomena ini menyebabkan menurunnya konsentrasi belajar siswa yang menyebabkan siswa mudah bosan dalam mengikuti pembelajaran.

Melihat berbagai faktor di atas, memunculkan bukti bahwa munculnya perilaku yang tidak diinginkan oleh siswa ketika di dalam kelas tidak hanya terpaku pada materi yang diberikan oleh guru akan tetapi pada situasi dan kondisi siswa dan lingkungan belajar. 
Permasalahan siswa ketika dalam pembelajaran cenderung kurang diperhatikan oleh guru, sehingga akan sulit keberhasilan yang dicapai bilamana tidak adanya pembenahan, baik dari aspek tata kelola pembelajaran, media pembelajaran, serta lingkungan yang produktif. Artikel ini bertujuan untuk menyajikan solusi alternatif guna meningkatkan kualitas proses pembelajaran melalui media musik, pengelolaan tata ruang belajar dan pencahayaan.

Dalam penelitian yang dilakukan oleh Gallup (Sousa 2012) menyatakan bahwa dari 800 peserta didik usia 13-17 tahun telah memilih jawaban bahwa sekolah adalah tempat yang membosankan (50\%) dan melelahkan (42\%). Bagaimana tidak, proses pembelajaran yang berlangsung sampai berjam-jam di sekolah tidak lebih dari kegitan masuk ke kelas, duduk rapi, mendengarkan materi dari guru dan ironisnya tidak satupun materi yang mereka tangkap secara optimal (Muali, 2016).

Peran musik, tata ruang, dan pencahayaan dalam pembelajaran merupakan satu kesatuan yang tidak dapat dipisahkan dan dianggap penting untuk mengemas suatu pembelajaran agar lebih produktif serta mendukung proses belajar mengajar sehingga akan meningkatkan konsentrasi belajar siswa. sebagaimana yang disampaikan oleh Jensen bahwa, otak manusia mampu menerima materi pembelajaran secara optimal bilamana lingkungan siswa dalam situasi yang kondusif (Eric Jensen, 2008).

Menurut (Sousa, 2012) Mendengarkan musik di dalam kelas kepada semua siswa, dapat mendorong mereka untuk tetap fokus dan produktif. Artinya bahwa musik merupakan salah satu alat yang difungsikan sebagai pendorong bagi siswa untuk menjaga tingkat konsentrasi dan produktivitas siswa. Desain ruang kelas yang baik dapat memberikan serta meningkatkan efektivitasnya dalam proses pengajaran.

Pendidikan Islam harus senantiasa mengutamakan dan mengembangkan berbagai metode maupun model pembelajaran baik secara intelektual maupun praktik. Maka perlu adanya pengembangan dari berbagai model pembelajaran sebagai wujud pendidikan Islam yang selalu terbuka dan berinovasi guna tercapainya insan kamil sebagaimana yang dicita-citakan oleh 
bangsa dan negara. Seperti halnya pemanfaatan berbagai aliran musik seperti musik religi dengan berbagai jenis dan aliran di dalamnya seperti Qasidah, Murottal, lagu Islami, tilawatil Qur'an dll, fungsinya yaitu menunjang fungsi otak serta menjunjung tinggi nilai-nilai ke Islaman dan spiritual siswa. Penggunaan musik diaplikasikan sesuai dengan fungsi dan tujuan yang digunakan sehingga menjadi mendorong bagi siapapun yang mendengarkan musik tersebut. Itulah pentingnya memperhatikan penggunaan otak manusia dalam merespon setiap pergerakan yang dilakukan oleh manusia. Sebagai bagian terpenting dari manusia, tentu otak memiliki peran yang sangat besar bagi manusia (Timotius, 2018).

Maka dari itu, penting kiranya untuk menggunakan salah satu metode pembelajaran berbasis otak (Neurosains). (Suyadi Suyadi, 2012) mengatakan bahwa pendidikan Islam memiliki jejak dalam ilmu syaraf, sedangkan neurosains adalah ilmu saraf yang mempelajari sistem saraf terutama mempelajari neuron dengan pendekatan multi displin (Pasiak, 2016). Otak merupakan salah satu keistimewaan yang Allah anugrahkan kepada manusia untuk berakal. Akal dalam pengertian Islam bukanlah otak, namun daya berpikir yang termasuk dalam jiwa manusia, daya yang sebagaimana diterangkan dalam Al Qur'an, memperoleh wawasan dengan memperhatikan dunia sekitar (Nasution, 2000). Dalam Al Qur'an banyak ayat mengarahkan kepada penggunaan akal dan terdapat lebih dari tiga belas kali kata "berpikir", karena dalam pandangan Islam akal memiliki kedudukan paling tinggi dibandingkan dengan agamaagama lain (Suyadi, 2019). Maka diharapkan pendidikan Islam untuk lebih memaksimalkan fungsi otak manusia agar selalu seimbang dan optimal karena selama ini kurang dioptimalkan khususnya dalam pendidikan Islam.

Adanya peran musik, pencahayaan dan tata ruang dalam pembelajaran sangatlah mendukung sehingga dapat diimplementasikan dalam pembelajaran Islam yang selama ini masih belum bisa dioptimalkan atau bahkan dihiraukan begitu saja. Sehingga diharapkan desain pembelajaran keagamaan yang berbasis pada neurosains mampu memberikan solusi 
yang tepat atas sedikitnya pemahaman guru terhadap model dan lingkungan belajar dalam pembelajaran.

\section{B. Metode Penelitian}

Adapun jenis artikel ini merupakan penelitian kualitatif yang didasarkan pada kajian kepustakaan yaitu serangkaian penelitian yang berkenaan dengan cara pengumpulan data kepustakaan (jurnal ilmiah, dokumen, buku, artikel dll (Sukmadinata, 2009). Adapun sifat dari penelitian ini merupakan deskriptif analisis yaitu penguraian secara teratur seluruh konsep kemudian pemberian pemahaman dan penjelasan dari hasil yang menjadi objek deskripsi. Teknik pengumpulan data dilakukan dengan menelusuri referensi terkait, baik secara manual maupun digital, terutama dalam data base google cendekia dengan kata kunci yang digunakan adalah desain pembelajaran pendidikan Islam, neurosains, musik, pencahayaan dan tata ruang.

Dari tiga puluh lima sumber dapat diklarifikasi dengan penelitian yang relevan dengan penelitian ini terdapat empat belas artikel, sehingga artikel ini mengkaji secara komprehensif terhadap empat belas artikel tentang desain pembelajaran pendidikan Islam berbasis neurosains yang terkait dengan musik, pencahayaan dan tata ruang. Setelah data tersebut terkumpul, langkah selanjutnya adalah melakukan penelaahan yang hubungannya dengan masalah yang diteliti, sehingga memperoleh data dan bahan untuk penelitian. Data yang terkumpul kemudian dianalisis secara kualitatif dengan melalui cara berpikir induktif.

\section{Hasil dan Pembahasan}

Berdasarkan telaah literatur dan metodologi penelitian ini disajikan dalam tiga sub tema yaitu :

\section{Peran Musik Dalam Pembelajaran Pendidikan Islam}

Dalam konteks pendidikan Islam, pemanfaatan dan pemahaman musik masih sangatlah kurang sebagai sarana dalam mendukung keberhasilan pendidikan. Sudah diketahui bersama bahwa musik hanya sebagai fokus materi dalam mata pelajaran seni budaya atau sebagai aransemen ketika menyanyikan lagu nasional. Ini menjadi bukti nyata bahwa musik masih jarang digunakan oleh pendidik sebagai fasilitator dalam 
membantu tugas guru dalam transfer ilmu. Musik hadir dalam berbagai aliran di lapisan masyarakat Indonesia, baik ketika acara keagamaan, adat maupun keluarga. Musik selalu hadir sebagai warna dalam acara tersebut dengan berbagai ciri khas yang ada di dalamnya, dari bukti yang ada apakah musik mampu berperan dalam dunia pendidikan, khususnya pendidikan Islam?, pemutaran musik dalam pembelajaran tidak hanya sebagai hiburan semata bagi siswa, maka menurut (DePorter et al., 2010), mereka mengungkapkan bahwa

"dengan menggunakan musik khusus, seperti musik klasik atau musik murottal, maka sangat mampu membantu mengerjakan tugas yang melelahkan sambil rileks dan konsentrasi, karena seiring dengan denyut nadi dan juga tekanan darah menurun, gelombang otak manusia juga akan melambat dan otot-otot menjadi rileks".

Media musik merupakan salah satu media audio yang sangat diminati oleh siswa dalam menyampaikan materi pembelajaran. Musik mampu menarik perhatian siswa dan memusatkan kembali konsentrasi siswa ketika sudah mulai jenuh dan lelah pada saat pembelajaran. (Giri Wiarto, 2016)

Kemudian (Mucci \& Mucci, 2000) mendefiniskan bahwa Bunyi dalam musik ialah bunyi yang teratur, sehingga memiliki daya tarik terhadap setiap orang yang mendengar dan memaknainya. Bunyi dalam musik adalah bunyi yang memiliki aturan, harmoni, dan tujuan. Sehingga memiliki daya tarik bagi orang yang mendengarkannya dengan berbagai sekte serta aliran yang berbeda-beda, karena setiap orang memiliki aliran musik yang berbeda-beda antara manusia satu dengan yang lain sesuai dengan kebutuhannya, sebagaimana yang dijelaskan oleh (Saifurrahman, 2019) bahwa musik memiliki bebarapa kelebihan, karena musik bersifat membuat rileks, nyaman dan damai. Menurut (Wijaya, 2018) Pengolahan dan penyimpanan informasi akan sangat efektif apabila tubuh dan otak dalam keadaan waspada yang rileks. Meditasi dengan bantuan musik dan aroma yang menenangkan akan mempercepat seseorang untuk masuk kedalam keadaan waspada yang rileks. Pada keadaan tersebut gelombang di otak menjadi 
lambat (gelombang alfa) yang membuka pintu ke bawah sadar.

\section{Kemudian beberapa ahli} menyatakan bahwa, musik memiliki manfaat yang banyak yang mencakup berbagai aspek baik fisik, mental maupun sosial. Kemudian (Sheppard, 2007) menambahkan dalam karya ilmiahnya bahwa semula para ahli mengemukakan bahwa informasi musik hanya diproses di salah satu belahan otak saja yakni belahan otak kanan. Argumentasinya karena musik berkaitan dengan intuisi, irama, dan kreatifitas. Sejumlah hasil penelitan yang muncul pada tahun 1990an menjelaskan hal berbeda.

\begin{abstract}
"Musik tidak hanya diproses oleh satu bagian otak. Para Ilmuwan menemukan bahwa musik diproses oleh jaringan saraf yang luas, tempat wilayah-wilayah otak yang berbeda-beda bekerja bersamasama untuk mengartikan hal-hal seperti melodi, harmoni dan ritme".
\end{abstract}

Kemudian (Chamidiyah, 2015) mengungkapkan bahwa jika perkataan digabungkan dengan musik atau gambargambar dan juga melibatkan emosi di dalamnya, maka perkataan tersebut menjadi lebih mudah dicerna dan diingat. Artinya, bilamana musik dapat dikemas dalam suatu pembelajaran maka akan mempermudah guru dalam menyampaikan sebuah materi.

Di antara aliran musik yang ada di dunia, musik religi merupakan salah satu aliran musik yang mana isinya berkaitan dengan pendidikan Islam (ajaran-ajaran agama) yang isi pada lirik dan sya'irnya mengandung makna yang berkaitan dengan pesan, dan lebih mendekatkan pendengarnya dengan Sang Pencipta. Kemudian (Djohan, 2006) mendeskripsikan bahwa musik religi adalah hiburan yang menyenangkan yang mendekatkan kita dengan Sang Pencipta. Ia juga menambahkan bahwa kekuatan musik religi terdapat pada lirik atau syair, karena memiliki makna yang lebih mendalam. Liriknya mampu menenangkan hati dan menggugah pendengarannya, sehingga perasaanya meningkat untuk menambah ketebalan iman kepada Tuhan. Sehingga relevansi antara musik religi dan pendidikan Islam merupakan suatu hubungan yang tidak bisa dipisahkan dan saling berhubungan keduanya memiliki tujuan akhir yang sama yaitu menjadikan insan kamil. 
Menurut (Ali, 1997) Insan kamil berasal dari bahasa Arab, yaitu "insan" dan "kamil" yang berarti manusia sempurna. Senantiasa mendekatkan antara hamba dan penciptanya Sehingga sangat cocok bilamana musik religi mampu diinternalisasikan sebagai media dalam mata pelajaran pendidikan Islam.

Adapun manfaat musik religi dalam pembelajaran PAI antara lain: a. Dapat memperjelas kajian materi keagamaan. b. Meningkatkan perhatian siswa ketika proses pembelajaran agama. c. Membantu siswa dalam peningkatan ilmu agama. d. Meningkatkan hasil belajar. e. Membangkitkan minat dan motivasi siswa dalam belajar agama. $f$. Menyajikan materi lebih menarik dan tidak monoton. g. Pembelajaran lebih interaktif. h. Meringankan beban/tugas guru dalam menjelaskan pelajaran (Azhar Arsyad, 2002). Adanya manfaat musik dalam pembelajaran pendidikan Islam memiliki timbal balik yang kompleks terhadap input pengetahuan yang dimiliki oleh siswa, sehingga berpengaruh terhadap kecerdasan siswa. Menurut (Mihalcea \& Strapparava, 2012) menjelaskan bahwasannya terdapat sepuluh jenis kecerdasan manusia yakni: Kecerdasan bidang matematika, Kecerdasan bidang bahasa, Kecerdasan bidang spasial, Kecerdasan bidang musik, Kecerdasan komunikasi, Kecerdasan kinestetis, Kecerdasan komunikasi pribadi, Kecerdasan naturalis, kecerdasan eksistensial dan Kecerdasan spiritual.

Dalam konteks pendidikan, yang menjadi fokus dalam penelitian ini yaitu kecerdasan dalam bidang musik dan spiritual, musik berperan sebagai alat dalam mengasah kecerdasan sedangkan kecerdasan spiritualis lebih cenderung kepada pendidikan Islam, sehingga adanya musik menjadikan pendidikan Islam lebih berwarna sebagai media pendukung dalam pendidikan.

Dari penjelasan para ahli dapat diambil garis tengah bahwa musik sangatlah berperan terhadap pola fikir dan kecerdasan siswa maupun konsentrasi siswa untuk tumbuh berkembang lebih baik. Menarik kembali berbagai permasalahan yang ada berbagai fenomena yang ada di lapangan bahwa siswa akan mudah hilang konsentrasi dan fokus ketika beberapa menit mengikuti pembelajaran karena dianggap membosankan dan tidak ada 
hal yang baru. Akan tetapi bila ditarik lurus dengan sebuah konser musik yang diidolakan apakah seseorang yang menonton akan mudah bosan ? secara tidak langsung seluruh badan akan ikut bergerak mulai dari kepala, tangan, kaki, jari jemari dan lain-lain. Semua merupakan sebuah rangsangan yang diterima otak yang kemudian menjadi sebuah gerakan, tentunya ini dapat menjadi sebuah acuan bahwa musik akan menjadi hal yang menarik ketika didesain dan dikemas ke dalam sebuah pembelajaran. Dalam prosiding Lyrics, Music, and Emotions, pernah dibahas bahwa kombinasi antara musik dan lirik dapat mempengaruhi emosi para pendengar, dan bahkan mampu menciptakan perasaan yang dalam (Mihalcea \& Strapparava, 2012). Oleh karena itu, musik dapat mengaktifkan gelombang otak seseorang, sehingga otak selalu dalam keadaan siap menangkap segala informasi untuk membantu memindahkan informasi tersebut ke memori dalam jangka yang panjang.

(Choksy, 1986) dalam (Milyartini, 2012) menjelaskan Jaques Dalcroze seorang komponis dan ahli pendidikan musik dari Swiss melakukan sejumlah eksperimen dan pengamatan berkaitan dengan gerak dan musik, selama hampir dua tahun dan kemudian menemukan suatu postulat tentang "kinesthetic sense". Postulat tersebut berbunyi :

"bila tubuh bergerak, sensasi gerakan akan diubah menjadi perasaan (feeling) yang dikirim melalui sistem syaraf ke otak. Otak akan mengubah informasi (sensory information) ini menjadi pengetahuan. Otak akan kembali mengirim informasi tersebut ke tubuh melalui sistem syaraf. Perintah ini melibatkan aktivitas mental seperti perhatian, konsentrasi, memori, keinginan yang kuat dan motivasi"

Artinya bahwa gerak tubuh manusia dapat dipengaruhi oleh perasaan manusia itu sendiri yang dikirim oleh otak, dan dari otak akan memberikan sebuah pengetahuan yang hasil akhirnya adalah meningkatkan energi positif pada manusia seperti konsentrasi, fokus, mental dan motivasi. Sebagaimana yang dijelaskan oleh Pasiak mengatakan bahwa dalam bidang ilmu saraf mendapatkan beberapa bukti antara tingkah laku manusia dan otak tidak dapat dipisahkan (Pasiak, 2012). Kemudian Mike Farle 
mendokumentasikan bahwa terdapat banyak lokasi di otak yang terangsang bila seseorang mendengarkan musik. Sepuluh wilayah tersebut meliputi : sensory cortex, auditory cortex, hippocampus, visual cortex, cerrebellum, amigdala, nucleus accumbens, prefrontal cortex, motor cortex dan corpus collosum.

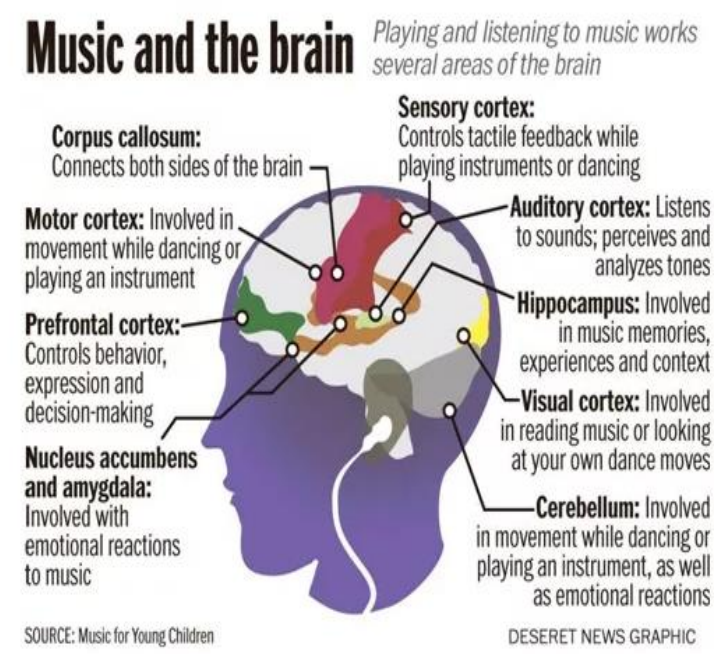

\section{Gambar 1. Sepuluh letak rangsangan otak manusia dalam mendengarkan musik. (Milyartini, 2012)}

Dari berbagai penjelasan di atas, maka sedikitnya terdapat sepuluh komponen utama dari manfaat penggunaan musik dalam pembelajaran sebagaimana diungkapkan oleh (Sheppard, 2007) manfaat musik adalah:

(1) Musik dapat mengubah bentuk otak.

(2) Meningkatkan keterampilan bahasa

(3) Mengembangkan fungsi mental (4)
Merangsang gerakan dan mengembangkan koordinasi dan kontrol fisik (5) Meningkatkan daya ingat dan penyimpanan informasi (6) Membantu memahami matematika dan sains (7) Mengembangkan keterampilan komunikasi dan mengekspresikan diri (8) ) Bantu anak-anak dalam kerja kelompok. (9) Membantu meningkatkan mood dan kesehatan fisik (10) Meningkatkan kreativitas.

\section{Desain Pencahayaan dan Pengaruhnya Terhadap Pembelajaran}

Desain pencayahaan dalam ruang belajar merupakan suatu hal yang penting, dan masih di anggap asing khusunya bagi pendidik di indonesia, padahal secara fakta salah satu cara agar siswa dapat melihat dan mengamati tulisan maupun gambar dalam buku yaitu melalui cahaya, sehingga mengoptimalkan penglihatan dan memberikan kenyamanan bagi siswa ketika sedang dalam kegiatan belajar mengajar. Cahaya adalah bagian penting dalam hidup manusia, karena kehidupan manusia sangat bergantung pada cahaya. Penyelidikan menunjukkan bahwa sekitar $80 \%$ dari semua informasi yang 
diterima oleh otak kita ternyata melalui mata. Proses tersebut hanya dapat terjadi bila ada cahaya, baik cahaya alami yaitu cahaya matahari langsung (day light) atau cahaya matahari yang dipantulkan oleh bulan (moon light) maupun cahaya buatan (artificial light) (Puspakesuma, 1991). Dari pernyataan tersebut dapat disimpulkan bahwasannya otak akan mudah merespon segala apapun melalui mata yang dibantu bantu oleh cahaya, maka dalam konteks pendidikan, pencahayaan yang baik sangatlah mendukung siswa ketika pencahayaan mampu diatur dengan baik. Menurut (Awhinarto \& Suyadi, 2020) Perilaku manusia pada dasarnya dikontrol oleh sistem saraf dalam otak, sehingga seluruh perilaku yang dilakukan oleh manusia sejatinya bermuara pada fungsi otak yang bekerja penuh agar mampu untuk memberikan stimulus terhadap suatu rangsangan yang dilakukan. Seperti halnya mata yang melihat suatu objek karena adanya cahaya yang kemudian akan di rangsang oleh otak dan akan menghasilkan sebuah respon berupa perilaku, refleks dan detak jantung.

Sistem penglihatan pada manusia merupakan salah satu bagian penting dari berbagai unsur yang membantu mata agar mampu melihat dengan sempurna. Sistem penglihatannya adalah sebagai berikut :

1. Mata manusia berfungsi sebagai photo receptor dalam menerima rangsangan berupa objek visual/cahaya melalui retina mata.

2. Oleh retina rangsangan dirubah menjadi sinyal-sinyal elektrik yang diteruskan pada bagian otak (Lateral Geniculate Nucleus).

3. Pada Lateral Geniculate Nucleus sinyal elektrik tersebut digabungkan dengan referensi (pengalaman dan latar belakang) yang sudah ada pada ingatan sebelumnya.

4. Kemudian sinyal elektrik tadi diteruskan pada bagian otak lain yaitu visual cortex, di dalam visual cortex sinyal elektrik tadi diubah menjadi sebuah persepsi dari manusia.

5. Karena persepsi tersebut maka rangsangan akan diteruskan pada organ tubuh lain yang akhirnya menghasilkan sebuah output berupa perilaku, gerak 
refleks, detak jantung, dan lain lain (Wibisono, 2009).

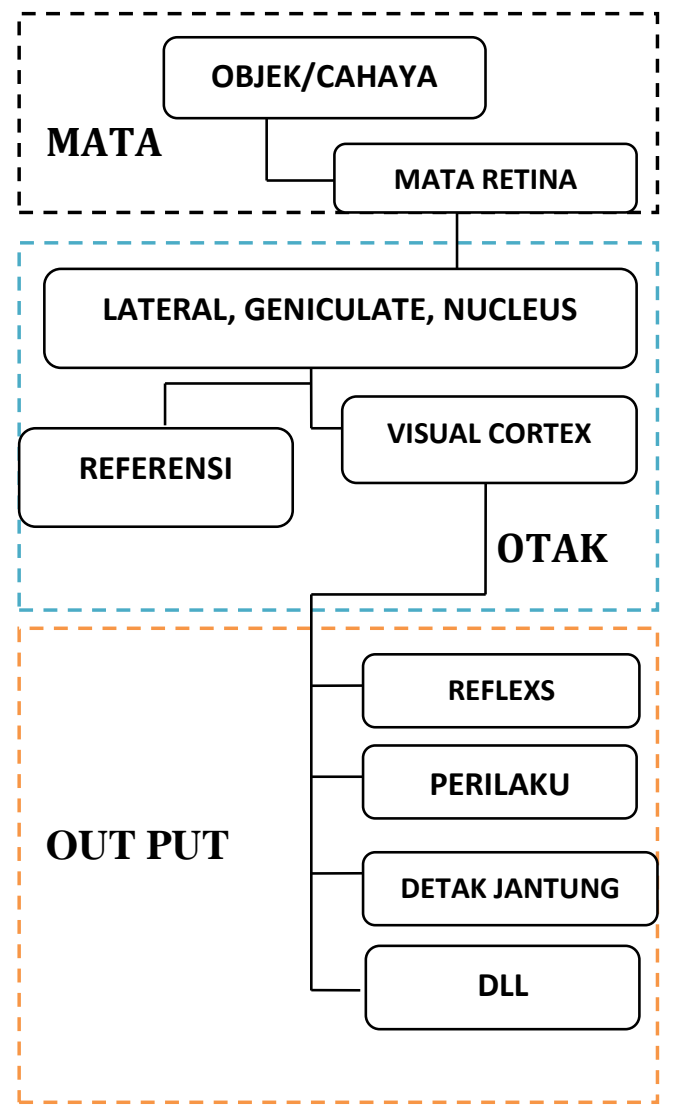

Gambar 2. Bagan Sistem Penglihatan Manusia. (Wibisono, 2009)

Pencahayaan/penerangan bagi manusia merupakan suatu kebutuhan vital agar mata mampu merespon suatu objek dengan baik, maka perlu sebuah tata kelola pencahayaan yang baik. Menurut (Suma'mur, 2009) Penerangan yang baik merupakan penerangan yang memungkinkan orang yang sedang ber aktivitas dapat melihat objek yang dikerjakannya dengan jelas, cepat dan tanpa sebuah upaya yang tidak perlu.
Kemudian (Mangunwijaya, 2000) berpendapat bahwa penerangan yang baik adalah apabila mata kita dapat melihat apa yang ada di sekitar kita dengan jelas dan nyaman, atau dengan kata lain penerangan harus dapat memenuhi persyaratan fungsional dan persyaratan keamanan. Kurangnya cahaya yang diterima atau cahaya berlebih yang ditangkap oleh mata merupakan suatu penyimpangan terhadap pencahayaan, maka dari itu perlu suatu standar pencahayaan yang baik dalam sebuah ruang pembelajaran. Menurut (Saifurrahman \& Suyadi, 2019) menjelaskan bahwa Standar pencahayaan ruang belajar yang baik di Indonesia adalah 250-300 lux. Lampu yang digunakan disarankan adalah lampu yang cahayanya tidak terlalu terang dan tidak terlalu redup sehingga cahayanya mampu menyatu dengan cahaya alami.

Ruang belajar merupakan salah satu hal penting dalam sekolah, berbagai usaha sering dilakukan agar mampu memaksimalkan pembelajaran, sehingga akan memberikan berbagai faktor positif pada siswa. Mungkin secara umum untuk intensitas penerangan harus memadai dan sesuai dengan kebutuhan 
INTIQAD: JURNAL AGAMA DAN PENDIDIKAN ISLAM

ISSN 1979-9950 (print) || ISSN 2598-0033 (online), http://jurnal.umsu.ac.id/index.php/intiqad

DOI: intiqad.v\%vi\%i.5836

Vol. 13, No. 1 (June 2021)

siswa. (Van \& Setiawan, 1985) menjelaskan bahwa intensitas sebuah cahaya perlu diperhatikan dengan baik agar mampu menghasilkan kesesuaian kebutuhan penglihatan di dalam sebuah ruang berdasarkan jenis aktivitas yang ada di dalamnya. Seperti, perpustkaan, laboratorium ruang kelas, studio dan lain sebagainya, karena setiap ruangan mempunyai kebutuhan intensitas pencahayaannya yang berbeda-beda. Artinya bahwa pencahayaan dibedakan sesuai dengan jenis kegiatan dan aktivitas yang ada di dalamnya dan disesuaikan dengan kebutuhanya seperti halnya perpustakaan, studio musik, ruang kelas dll.

Metode dari sistem pencahayaan SNI 2001 meliputi Penentuan tingkat pencahayaan minimum (E) yang direkomendasikan. Tingkat pencahayaan minimum yang direkomendasikan tercantum dalam tabel 1 sebagai berikut :

Tabel 1. Tingkat Pencahayaan ratarata, temperatur dan renderansi warna yang direkomendasikan.

\begin{tabular}{|c|c|c|c|}
\hline $\begin{array}{c}\text { Fungsi } \\
\text { Ruangan }\end{array}$ & $\begin{array}{c}\text { Tingkat } \\
\text { Pencahaya } \\
\text { an }\end{array}$ & $\begin{array}{c}\text { Kelompok } \\
\text { Renderasi }\end{array}$ & Ket. \\
\hline $\begin{array}{c}\text { Lembaga } \\
\text { Pendidikan }\end{array}$ & \multicolumn{3}{|l|}{} \\
\hline Ruang Kelas & 250 & $1-2$ & - \\
\hline
\end{tabular}

\begin{tabular}{|l|c|c|c|}
\hline Perpustakaan & 300 & 1 atau 2 & - \\
\hline Laboratorium & 500 & 1 & - \\
\hline $\begin{array}{l}\text { Ruang } \\
\text { Gambar }\end{array}$ & 750 & 1 atau 2 & - \\
\hline Kantin & 200 & 1 & - \\
\hline
\end{tabular}

Jenis - Jenis Pencahayaan

\section{a. Pencahayaan Alami}

Pencahayaan alami merupakan pencahayaan yang sumber cahaya tersebut berasal dari alam, seperti matahari, bulan dan bintang. Matahari adalah sumber pencahayaan yang paling utama, pencahayaan alami digunakan oleh manusia sebagai sumber pencahayaan yang berperan penting dalam kelangsungan hidup manusia. Sumber pencahayaan alami bergantung pada tempat dan waktu (siang hari atau malam hari), musim, dan cuaca (cerah, mendung, berawan, dll). sebagaimana yang diwahyukan oleh Allah SWT, dalam Q.S Al-Mu'min ayat 61 yang berbunyi :

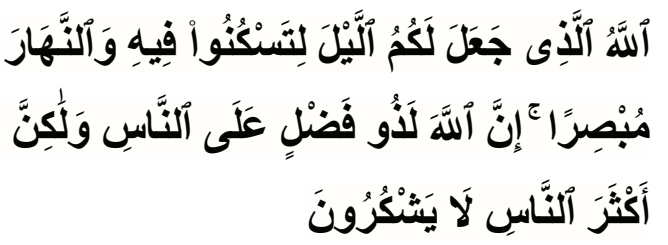

Artinya : Allah-lah yang menjadikan malam untuk kamu supaya kamu beristirahat padanya; dan menjadikan siang terang 
benderang. Sesungguhnya Allah benar-benar mempunyai karunia yang dilimpahkan atas manusia, akan tetapi kebanyakan manusia tidak beryukur. (Q.S Al-Mu'min : 61).

Dari ayat tersebut dapat diketahui bahwa Allah SWT. Sudah menciptakan dan menaqdirkan bahwa waktu siang Allah perlihatkatkan segala hal yang ada dibumi agar manusia dapat menyaksikan apapun yang ingin dilihat dan menjadikan malam hari untuk istirahat, dan semua hanyalah kebesaran yang Allah miliki agar senantiasa disyukuri oleh seluruh umat manusia.

\section{b. Pencahayaan Buatan}

Pencahayaan buatan adalah pencahayaan yang berasal dari sumber cahaya buatan manusia yang dikenal dengan lampu atau luminer melalui listrik pada tiap-tiap jaringannya. Pencahayaan buatan lebih berpengaruh sebagai pengganti dari pencahayaan alami dan lebih umum digunakan pada malam hari Pada cuaca yang kurang baik dan malam hari. pencahayaan buatan sangat dibutuhkan.

Dalam mendesain tata ruang pembelajaran perlu menjadi perhatian pada tiap-tiap media yang digunakan seperti halnya papan tulis White Board/Black boar, lcd proyektor. Sehingga tidak merusak konsentrasi dan pandangan siswa. pada media White board pencahayaan yang disarankan adalah 250 lux, sedangkan pada Black board yang daya pantulnya tidak lebih dari 0,1 maka kuat pencahayaan yang disarankan adalah 500 lux. Sedangkan ruang kelas yang menggunakan media LCD, pencahayaan umum yang disarankan adalah 250-300 lux. Kemudian menurut (Subagyo, 2017) menjelaskan bahwa lampu yang dipakai dalam ruang kelas sebaiknya lampu dengan warna cahaya putih netral yang cahayanya dapat menyatu dengan baik dengan cahaya alami, karenanya disarankan lampu dengan temperatur sekitar 4000 K. Jenis lampu yang disarankan untuk ruang kelas dengan tinggi sampai dengan $3 \mathrm{~m}$. Semua di atur dan dikaji guna membantu siswa dan pendidik dalam menjaga fokus siswa dalam pembelajaran.

\section{c. Syarat Pencahayaan}

Pencahayaan yang baik dalam ruang belajar merupakan hal penting dalam mendukung dalam pembelajaran, 
lalu bagaimanakah kualifikasi pencahayaan yang baik dalam desain pencahayaan di dalam kelas? menurut (Saifurrahman, 2019) menerangkan bahwa Sumber pencahayaan yang baik adalah dengan intensitas yang tidak menyilaukan, menyebar merata, tidak berkedip-kedip, dan tidak menimbulkan pantulan atau bayangan pada objek tertentu dan intensitasnya harus selalu diukur dengan beban aktivitas belajar mengajar. Aktivitas mata yang terus menerus akan terjadi ketegangan mata dan kelelahan mata. Kelelahan mata adalah ketegangan pada mata yang disebabkan oleh penggunaan indera penglihatan dalam bekerja yang memerlukan kemampuan untuk melihat dalam jangka waktu yang lama dan biasanya disertai dengan kondisi pandangan yang tidak nyaman.

Sehingga akan memunculkan beberapa gejala kelelahan pada mata yang sering muncul seperti : kelopak mata terasa berat, penglihatan seperti berkabut walau mata difokuskan, bagian mata paling dalam terasa sakit, perasaan mata berkedip, penglihatan kabur, tidak bisa difokuskan, penglihatan terasa silau, mata merah, mata mudah berair, mata pedih dan berdenyut, tidak dapat membedakan warna sebagaimana biasanya, ada sisa bayangan dalam mata, penglihatan tampak double, mata terasa panas serta mata terasa kering.

Gejala tersebut tidak hanya dirasakan oleh anak usia muda akan tetapi semakin tua umur manusia maka, kualitas penglihatan juga semakin menurun. Dalam kualifikasi pencahayaan dalam kelas antara SD/SMP/SMA memiliki perbedaan yang signifikan sebagaimana yang dituliskan oleh (Subagyo, 2017) bahwa ruang kelas ditinjau dari segi umur pengguna ruang ada yang bersifat homogen, seperti ruang kelas untuk SD umurnya 6- 12 tahun, SMP umur 13-16 tahun, SMA 17- 20 tahun, perguruan tingggi diatas 20 tahun. Pengaruh umur terhadap penglihatan sangat berpengaruh, secara umum makin tinggi umur manusia daya penglihataanya makin berkurang. Sehingga intensitas penerangan pada bidang kerja 200 lux menurut anak umur 10 tahun berbeda dengan orang yang sudah berumur 60 tahun. 


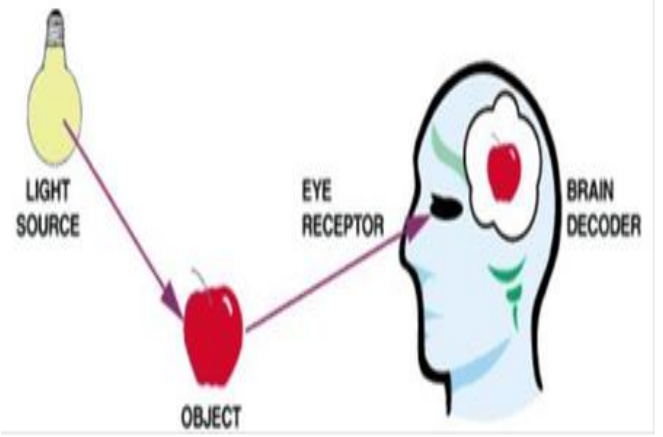

Gambar 3. respon mata dan otak terhadap objek yang dilihat dari pencahayaan. (Saifurrahman Suyadi, 2019)

\section{Desain Tata Ruang Dalam}

\section{Pembelajaran Pendidikan Islam}

Dalam menunjang keberhasilan sebuah pembelajaran islam tentunya perlu dukungan dari berbagai lini dan sisi yang saling mensuport antara satu dengan yang lain tak terkecuali desain tata ruang kelas. Ruang kelas adalah tempat untuk melaksanakan transfer ilmu baik teori maupun praktek dengan tidak memerlukan peralatan khusus sebagai pendukung. (Bafadal, 2001) Menjelaskan bahwa untuk menciptakan ruang kelas yang aman dan nyaman selama proses pembelajaran perlu dilakukan penataan seperti layout ruangan, furniture dan media. Dengan demikian, melalui penataan ruang yang baik dapat membantu mekanisme kerja berjalan dengan lancar dan membawa kedamaian, ketenangan dan keseruan belajar bagi siswa.

Ruang kelas harus memiliki jendela yang cukup agar pencahayaannya dapat mendukung dan menunjang membaca serta memberikan pemandangan ke luar ruangan (Permendiknas, 2007). Tata ruang adalah penataan atau penyusunan semua fasilitas di ruang atau gedung yang tersedia dengan sebaik-baiknya agar mampu memberikan kemudahan dan kenyamanan bagi siapapun yang menempatinya.

(Maryana \& Rachmawati, 2013) menyatakan bahwa, suatu kondisi ruangan belajar dapat mempengaruhi kualitas pembelajaran didalamnya. Tentunya untuk bisa merealisasikan hal tersebut perlu langkah serius bagi pendidik untuk memahami secara makro tetang desain tata ruang agar terciptanya ruang belajar yang aman dan nyaman. Kebutuhan siswa dalam ruang kelas adalah memperoleh rasa bebas, aman, nyaman dan hangat. Sehingga perlu didukung dengan kualitas ruangan yang baik, dalam arti sempit seperti halnya ruangan kelas sebagai tempat 
berlangsungnya pembelajaran secara terus menerus. Dalam konteks desain interior, ruang dapat merangsang dan menstimulasi kecerdasan emosional anak secara psikologis, sehingga mereka dapat belajar sesuai dengan usianya.

Kemudian, (DePorter et al., 2010) menjelaskan bahwa Faktor tata letak ruang kelas adalah kunci untuk menciptakan lingkungan belajar yang baik. Memilih jenis furnitur, tata letak, warna, pencahayaan, musik, poster visual, gambar, suhu, kenyamanan dan suasana hati secara keseluruhan adalah kunci untuk menciptakan lingkungan belajar yang baik secara fisik maupun mental.

Faktor penataan ruang kelas merupakan kunci untuk menciptakan lingkungan belajar yang optimal. Pemilihan jenis perabotan, penataan, warna, pencahayaan, musik, visual poster, gambar, temperatur, tanaman, kenyamanan, dan suasana hati secara umum merupakan kunci menciptakan lingkungan yang optimal, baik secara fisik maupun mental. Dari kutipan tersebut dapat dijelaskan bahwa secara menyeluruh desain tata ruangan harus disesuaikan dengan kebutuhan dan perkembangan siswa, maka tidak bisa disamakan antara tata ruang siswa TK/SD/SMP/SMA atau bahkan perguruan tinggi, karena masing masing memiliki kepribadian yang berbedabeda.

Dengan mengelola tata ruang kelas dan menggunakan media yang disesuaikan dengan kebutuhan siswa, maka dapat meningkatkan minat belajar siswa. Mengatur tata ruang kelas maksudnya adalah mendesain dan mengatur ruang kelas sedemikian rupa sehingga pendidik dan anak didik itu kreatif. Seperti mengatur meja, kursi, papan tulis, maupun hiasan di dalam kelas.

Beberapa upaya sederhana dapat dilakukan oleh guru dalam menata ruang belajar siswa seperti memajang hasil kerajinan siswa, kaligrafi atau tulisantulisan islami seperti kawasan wajib berbusana muslim, sehingga diharapkan mampu memberikan motivasi bagi peserta didik untuk belajar lebih baik dan menumbuhkan inspirasi bagi peserta didik lain, serta menumbuhkan nilai-nilai spiritual sehingga mempengaruhi psikologis serta rangsangan otak pada siswa dalam hal ini adalah motivasi. 


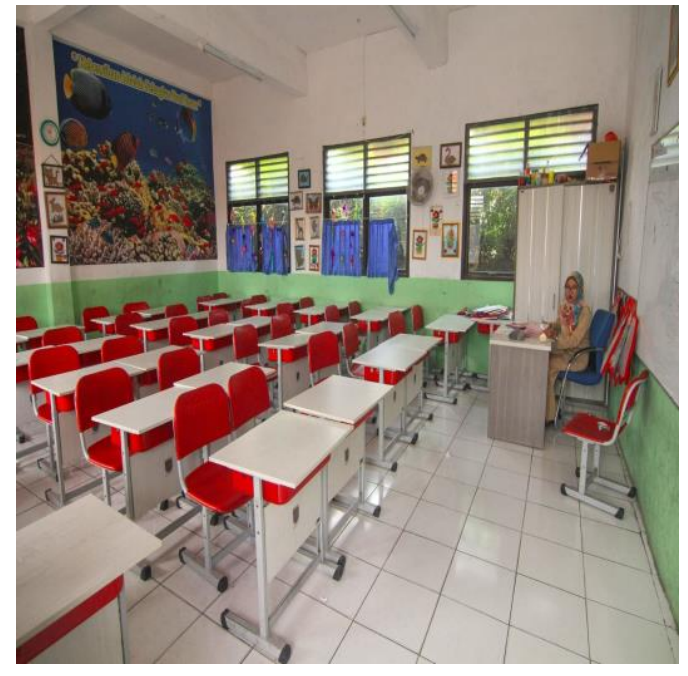

Gambar 3. Ruang kelas dengan pencahayaan yang baik dan karya siswa di dinding kelas. (Ashari, 2020)

\section{Hal-hal Yang Perlu di Perhatikan Dalam Mendesain Ruang Belajar}

Terdapat beberapa hal yang harus diperhatikan oleh pendidik dalam mendesain ruang belajar seperti, tidak menjadikan siswa merasa tidak nyaman karena penataan ruang yang terlalu sempit, sehingga siswa tidak bisa bergerak leluasa ketika belajar, memudahkan siswa berinteraksi dan berkomunikasi dengan siswa lain, beberapa hal tersebut perlu diperhatikan oleh guru sebelum menata/mendesain ruang kelas. (Djamarah \& Zain, 2006) menjelaskan bahwa terdapat beberapa hal yang perlu diperhatikan dalam mengatur sebuah tata kelola ruang, seperti : Jumlah siswa dalam kelas, jumlah siswa pada setiap kelompok, ukuran kelas, bentuk kelas, ukuran bangku dan meja siswa, Jumlah kelompok dalam kelas, komposisi pada masing-masing kelompok seperti siswa yang aktif dan kurang aktif atau siswa laki-laki dengan siswa perempuan.

Dari uraian tersebut dapat disimpulkan bahwa menata ruang belajar tidak dapat dilaksanakan secara semena-mena artinya, harus mempertimbangkan berbagai obyek dan subyek yang ada di sekitarnya, seperti ukuran kelas, jumlah siswa, jumlah kelompok dalam satu kelas. Dalam melaksanakan penataan ruang belajar guru menjadi penanggung jawab utama dalam menjaga dan mengarahkan kegiatan tersebut dari awal hingga akhir agar sesuai dengan apa yang diharapkan.

Desain tata ruang belajar hakikatnya dilaksanakan agar terwujudnya optimalisasi efektivitas sebuah pembelajaran. Terdapat beberapa model penataan tempat duduk yang dapat digunakan dalam mendesain tata ruang sebagaimana yang dijelaskan oleh (Lie, 2005) sebagai berikut : Meja 
tapal kuda, siswa berkelompok diujung meja, Penataan tapal kuda, siswa dalam satu kelompok ditempatkan berdekatan, meja panjang, meja kelompok, klasial, siswa dalam satu kelompok ditempatkan berdekatan, siswa dalam satu kelompok berdekatan. meja berbaris, dua kelompok duduk dalam satu meja, bangku individu dengan meja tulisnya, penata terbaik, meja berbaris, dua kelompok duduk berbagi dengan satu meja.

Beberapa indikator diatas dapat menjadi tolak ukur dan panduan bagi guru agar mampu mengelola segala hal yang berkaitan dengan penataan ruang baik yang bersifat fisik maupun non fisik. Adanya penataan ruang dalam pembelajaran memilki tujuan, dari diadakannya tata ruang pembelajaran. Sebagaimana yang diuraikan dalam Dirjen Dikdasmen bahwa tujuan tata ruang kelas adalah:

1. Memuwujudkan situasi dan kondisi kelas baik sebagai lingkungan belajar maupun sebagai tempat belajar, yang memungkingkan peserta didik dalam mengembangkan berbagai kemampuan yang ada pada dirinya.

2. Menghindarkan dari berbagai hambatan yang dapat menghalangi terwujudnya optimalisasi brlajar mengajar.

3. Mengatur serta Menyediakan fasilitas belajar yang mendukung dan memungkinkan siswa belajar sesuai dengan lingkungan sosial, emosional, dan intelektual.

4. Membimbing siswa sesuai dengan latar belakang sosial, ekonomi, dan budaya serta sifatsifat individualnya.

Tujuan utama dari tata ruang kelas adalah memberikan fasilitas kepada siswa dalam hal penataan ruang, sehingga membantu siswa dalam memaksimalkan pembelajaran serta menghindari munculnya perilaku yang kurang baik pada siswa dan memberikan kenyamanan bagi siswa hingga menumbuh kembangkan kecerdasan berfikir kretaif. Sebagaimana yang jelaskan oleh (Anwar, 2016) menjelaskan bahwa ke kreatifan berpikir dilakukan berdasarkan proses keterlibatan mental seseorang dalam bertindak dan memilih yang paling baik dari berbagai pilihan berasaskan kategori 
INTIQAD: JURNAL AGAMA DAN PENDIDIKAN ISLAM

ISSN 1979-9950 (print) || ISSN 2598-0033 (online), http://jurnal.umsu.ac.id/index.php/intiqad

DOI: intiqad.v\%vi\%i.5836

Vol. 13, No. 1 (June 2021) tertentu. selain tujuan penataan ruang belajar terdapat prinsip-prinsip yang harus di perhatikan oleh guru dalam menata ruang belajar.

\section{Prinsip Desain Tata Ruang Belajar}

Menurut (Karwati et al., 2014) terdapat beberapa prinsip yang patut menjadi perhatian guru/pendidik ketika menata ruang belajar, yaitu :

1. Visibilitas (keleluasan pandangan) Visibilitas artinya adalah penempatan dan penataan barangbarang di dalam kelas tidak mengganggu pandangan peserta didik, sehingga leluasa dalam memandang pendidik, benda atau kegiatan yang berlangsung.

2. Aksesibilitas (mudah dicapai)

Artinya bahwa penataan ruang harus dapat memudahkan peserta didik untuk meraih, barang-barang yang dibutuhkannya selama proses pembelajaran berlangsung.

3. Fleksibilitas (keluwesan)

Artinya barang-barang di dalam kelas hendaknya mudah ditata dan dipindahkan sesuai dengan kebutuhan pembelajaran.

4. Kenyamanan dan keindahan berkaitan dengan upaya guru dalam menata kelas yang menarik dan bermanfaat bagi proses pembelajaran dengan pencahayaan, suhu udara, akustik, dan kepadatan kelas sehingga dapat berpengaruh positif pada sikap dan tingkah laku peserta didik terhadap proses pembelajaran yang sedang dilaksanakan.

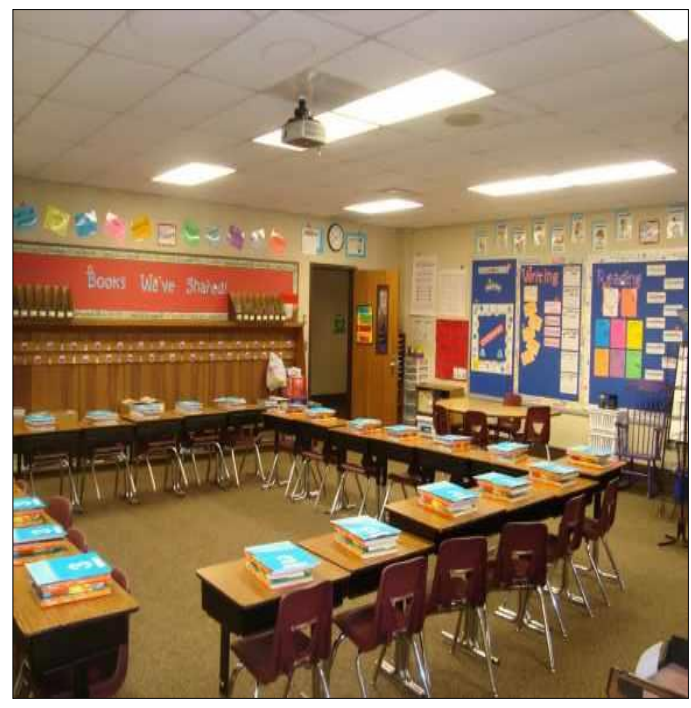

Gambar 4. Desain Ruang kelas dengan memperhatikan Visibilitas, Aksesibilitas dan Fleksibilitas. (Lestari, 2015)

Dari beberapa prinsip tersebut di atas dapat disimpulkan bahwa prinsip tata ruang kelas adalah visibilitas (keleluasan pandangan), aksesibilitas (mudah dicapai), fleksibilitas (keluwesan), dan keindahan ruangan. Adanya penataan tata ruang dalam 
pembelajaran tidak dilaksanakan secara tiba-tiba. Terdapat dua faktor yang mempengaruhi tata ruang kelas yaitu faktor internal dan eksternal, berikut penjelasannya :

a. Faktor Internal

Faktor internal merupakan faktor yang berasal dari dalam diri siswa. Misalnya jika terdapat siswanya yang fisiknya kurang sehat, kemungkinan siswa itu kosentrasi belajarnya akan terganggu dan akan mempengaruhi siswa lain yang berada di dekatnya.

b. Faktor eksternal

Faktor eksternal merupakan faktor yang berasal dari luar diri siswa. Seperti kondisi keluarga, lingkungan sekolah,lingkungan dan masyarakat. Seperti keadaan keluarga yang tidak baik atau ada masalah di lingkungan tempat tinggalnya memungkinkan siswa tersebut akan berbeda dengan siswa yang lain.

\section{Simpulan}

Dari hasil pembahasan di atas maka dapat diambil 4 kesimpulan sebagai berikut:

1. Musik, pencahayaan dan tata ruang merupakan hal penting dan perlu di apilikasikan dalam sebuah kegiatan pembelajar agama Islam. Selain penting, adanya musik, pencahayaan dan desain tata ruang juga memiliki efek yang besar terhadap pemaksimalan fungsi otak manusia sebagaimana yang sudah dijelaskan di pembahasan.

2. Musik menjadi hal yang perlu dalam sebuah pembelajaran karena dengan adanya musik otak manusia berfungsi secara menyeluruh terhadap pola fikir, fokus, dan tumbuh kembang siswa. Musik religi merupakan salah salah satu musik yang relevan dengan pendidikan Islam yaitu isi syairnya selalu mengingatkan pendengarnya mendekatkan dengan sang penciptanya. Pendidikan Islam dan Musik religi memiliki relevansi karena antar keduanya erat akan nilai-nilai religius antara manusia dengan Penciptanya musik religi dapat diimplementasikan dalam berbagai cara baik dalam pelajaran PAI maupun sebagai penumbuh rasa religius di lingkungan sekolah. 
Adanya musik juga memberikan respon pada perasaan manusia itu sendiri yang dipengaruhi oleh otak dan dari otak akan menghasilkan energi positif pada manusia itu sendri. Sehingga memiliki daya tarik terhadap siapaun yang mendengarkannya dan mampu memberikan rangsangan otak kepada peserta didik untuk aktif dalam berfikir.

3. Pencahayan merupakan salah satu syarat terpenting bagi manusia untuk melihat, $80 \%$ informasi yang diterima oleh manusia adalah melalui mata/penglihatan. Desain pencahayaan dalam kelas diatur sesuai dengan aktivitas yang ada di dalamnya sehingga mampu berjalan dengan baik dan mampu mendukung kerja otak siswa. Standar pencahayaan adalah 250300 lux. Lampu yang digunakan tidak terlalu terang dan tidak terlalu redup sehingga dapat menyatu dengan cahaya alami, menyebar dan tidak menimbulkan pantulan atau bayangan pada objek tertentu sehingga tidak menimbulkan efek lelah pada mata.

4. Desain tata ruang merupakan tata kelola tempat belajar siswa guna meningkatkan efektivitas belajar sisw dengan tujuan memberikan fasilitas kepala siswa dalam hal penataan ruang sehingga membantu memaksimalakan pembelajaran serta memberikan kenyamanan bagi siswa. Prinsip tata kelola ruang kelas adalah memberikan keleluasan, pandangan, mudah dicapai, keluwesan, kenyamanan dan keindahan ruangan.

\section{E. Daftar Pustaka}

Ali, Y. (1997). Manusia citra ilahi: pengembangan konsep insan kamil Ibn Arabî oleh al-Jîlî. Paramadina.

Anwar, B. (2016). Pendidikan islam melalui kemahiran berfikir membentuk moral dan akhlakul karimah pelajar islam. Al-Daulah, 5(2), 341-351.

Ashari, M. (2020). Proses Pembejalaran Daring di Tengah Antisipasi Penyebaran Virus Corona Dinilai Belum Maksimal.

PikiranRakyat.Com. https://www.pikiranrakyat.com/pendidikan/pr01353818/proses-pembejalarandaring-di-tengah-antisipasipenyebaran-virus-corona-dinilai- 
belum-maksimal

Awhinarto, A., \& Suyadi, S. (2020).

Otak Karakter Dalam Pendidikan Islam: Analisis Kritis Pendidikan Karakter Islam Berbasis Neurosains. Jurnal Pendidikan Karakter, 10(1).

Azhar Arsyad. (2002). Media Pembelajaran. Raja Grafindo Persada.

Bafadal, I. (2001). Pengelolaan Perpustakaan Sekolah, Jakarta: Bumi Aksara. Jakarta: PT. Raja Grafindo Persada.

Chamidiyah, C. (2015). Pembelajaran melalui Brain Based Learning Dalam PenDiDikan anak usia Dini. Edukasia: Jurnal Penelitian Pendidikan Islam, 10(2).

DePorter, B., Reardon, M., \& SingerNourie, S. (2010). Quantum teaching: mempraktikkan quantum learning di ruang-ruang kelas. Kaifa.

Djamarah, S. B., \& Zain, A. (2006). Strategi belajar mengajar. Jakarta: Rineka Cipta, 46.

Djohan. (2006). Terapi Musik: Teori dan Aplikasi. Galang Press.

Eric Jensen. (2008). Brain-based Learning: Pembelajaran Berbasis Kemampuan Otak. Pustaka Belajar.

Giri Wiarto. (2016). Media
Pembelajaran dalam Pendidikan Jasmani. Laksitas.

Karwati, E., Priansa, D. J., Somad, H. R., \& Kasmanah, A. (2014). Manajemen kelas (Classroom management): guru profesional yang inspiratif, kreatif, menyenangkan dan berprestasi. Alfabeta.

Lestari, D. (2015). Mengatur Layout Ruang Kelas. https://anakabk.wordpress.com/201 5/08/02/mengatur-layout-ruangkelas/

Lie, A. (2005). Cooperative Learning/Mempraktikkan Cooperative Learning di RuangRuang Kelas, Jakarta: PT. Grasindo, t. Th.

Mangunwijaya, Y. (2000). Pengantar Fisika Bangunan. Djambatan.

Maryana, R., \& Rachmawati, Y. (2013). Pengelolaan lingkungan belajar. Prenada Media.

Mihalcea, R., \& Strapparava, C. (2012). Lyrics, music, and emotions. Proceedings of the 2012 Joint Conference on Empirical Methods in Natural Language Processing and Computational Natural Language Learning, 590-599.

Milyartini, R. (2012). Peran Musik Bagi Anak Berkebutuhan Khusus (Diffable $=$ Different Abilities $)$. 
Muali, C. (2016). Konstruksi Strategi Pembelajaran Berbasis Multiple Intelligences Sebagai Upaya Pemecahan Masalah Belajar. PEDAGOGIK: Jurnal Pendidikan, $3(2)$.

Mucci, K., \& Mucci, R. (2000). The healing sound of music. Findhorn Press.

Nasution, H. (2000). Akal dan Wahyu dalam Islam. UI PRESS.

Pasiak, T. (2012). Pendidikan Karakter Sebagai Pendidikan Otak. In Mengatasi Masalah Narkoba dengan Welas Asih. Gramedia Pustaka Utama.

Pasiak, T. (2016). Tuhan Dalam Otak Manusia: Mewujudkan Kesehatan Spiritual Berdasarkan Neurosains. Mizan.

PERMENDIKNAS. (2007). 24.

Puspakesuma, D. (1991). Teknik Pencahayaan dan Tata Letak Lampu. Gramedia.

Saifurrahman, S. (2019). Desain Pembelajaran Keagamaan Islam Berbasis Neurosains. $A L$ MURABBI: Jurnal Studi Kependidikan Dan Keislaman, 6(1), 55-73.

Sheppard, P. (2007). Music makes your child smarter: peran musik dalam perkembangan anak. Gramedia Pustaka Utama.
Sousa, D. A. (2012). Bagaimana Otak Belajar Edisi Keempat. Jakarta: Indeks.

Subagyo, A. (2017). Kualitas Penerangan yang Baik Sebagai Penunjang Proses Belajar Mengajar di Kelas. Orbith: Majalah Ilmiah Pengembangan Rekayasa Dan Sosial, 13(1).

Sukmadinata, N. S. (2009). Metode penelitian pendidikan. PT. Remaja Rosdakarya. PT. Remaja Rosdakarya.

Suma'mur. (2009). Higene Perusahaan Dan Kesehatan Kerja. Sagung Seto.

Suyadi. (2019). Hybridization of Islamic Education and Neuroscience: Transdisciplinary Studies of'Aql in the Quran and the Brain in Neuroscience. Dinamika Ilmu, 19(2), 237-249.

Suyadi, Saifurrahman. (2019). Desain Pembelajaran Keagamaan Islam Berbasis Neurosains. Al-Murabbi, 6(1), 55-73.

Suyadi, Suyadi. (2012). Integrasi Pendidikan Islam dan Neurosains dan Implikasinya Bagi Pendidikan Dasar (PGMI). Al-Bidayah: Jurnal Pendidikan Dasar Islam, 4(1).

Timotius, K. H. (2018). Otak dan perilaku. Penerbit Andi. Penerbit Andi.

Van, H. P., \& Setiawan, E. (1985). 
INTIQAD: JURNAL AGAMA DAN PENDIDIKAN ISLAM

ISSN 1979-9950 (print) || ISSN 2598-0033 (online), http://jurnal.umsu.ac.id/index.php/intiqad DOI: intiqad.v\%vi\%i.5836

Vol. 13, No. 1 (June 2021)

Instalasi Listrik Arus Kuat, Jilid 2. Bandung: Percetakan Bina Cipta.

Wibisono, A. (2009). Hubungan antara

Penglihatan, Pencahayaan, dan

Persepsi Manusia dalam Desain

Interior. Ambiance, 2(2), 217750.
Wijaya, H. (2018). Pendidikan

Neurosains Dan Implikasinya Dalam Pendidikan Masa Kini. 